\title{
Private Providers and the Expansion of Collaborative Higher Education in the UK: Unintended Effects Of Deregulation?
}

\author{
Dr. John Mariampillai \\ Senior Lecturer, School of Business, Law and Computing, \\ Buckinghamshire New University, UK
}

\begin{abstract}
The higher education sector in the UK has witnessed major changes in recent times, including the expansion of private HE provision. Education has a special place in a society, and it plays a major role; it creates productive workforce, offers social mobility and contributes to the economic growth and prosperity of a nation. Therefore, the decision to open-up the higher education market to private providers has met with public debate and scrutiny. This article examines the existence, growth and the approaches adopted by the successive governments since 2010 to organise private provision in the UK higher education.
\end{abstract}

Keywords: policy; higher education; private providers; funding

\section{INTRODUCTION}

Like many other sectors in the UK, the Higher Education (HE) sector has been witnessing major and constant reforms. Ball (2007, p.18) commenting on the public sector reforms in the UK states that 'during Thatcher's terms as prime minister the landscape of economic and political understandings of welfare changed irrevocably'; the boundaries between the state, the economy and the public sector were 'discursively reconstituted'. This meant that some public sector systems were subjected to new modes of management that closely matched other commercial market institutions (Ball, 2013). Consequently, the sectors (including HE) that had close government steering in the past have now been embracing marketisation and marketlike behaviours (Jongbloed, 2003, p.113).

Furthermore, the Conservative-led Coalition Government's commitment to open the HE market has led to the expansion of private provision and the number of private providers gaining access to public-backed funding has increased since 2010. For example, the amount of tuition fee loans paid for 'designated courses' with private providers rose to $£ 165.7$ million in $2017 / 18$ from $€ 36$ million in 2011/12 (SLC, 2018) and there were 51,930 undergraduate students on designated courses at alternative providers ${ }^{1}$ in $2016 / 17$ (HESA, 2018). This remarkable growth in student numbers has created animated debates concerning the role of private providers - the idea of making a profit out of HE being vigorously rejected by some and defended by others. Consequently, private HE in the UK has become a focal topic in public discourse on higher education.

This article will examine the expansion of private providers in the UK HE and will argue that the growth of private providers in the UK is not a recent phenomenon. This paper will report on a discrete component of a larger study (Mariampillai, 2014) which examined collaborative

\footnotetext{
1 'Alternative providers (APs) are higher education providers who do not receive recurrent funding from the
} Funding Councils or other public bodies and who are not further education (FE) colleges' (HESA, 2018). 
HE in the UK. The present paper focuses specifically on the various ways in which the then Coalition Government attempted to organise private $\mathrm{HE}$, which in the past managed to operate partly outside the public policy framework.

\section{PRIVATE HE: IS EXPANSION A POST-2010 PHENOMENON?}

As outlined previously, studies on private HE in the UK have been limited in the past as it managed to operate partly outside the public policy framework attracting little and/or no attention from public HE policy discourse. A study on private HE providers in the UK commissioned by the Department for Business, Innovation and Skills (2013) found that there were 674 private HE providers in the UK in 2012 . Most providers were relatively small - 217 of the 674 had fewer than 100 students and only five providers had over 5000 students (Department for Business, Innovations and Skills, 2013). Another extensive study conducted in 2014, identified some 732 alternative providers of $\mathrm{HE}$ which between them had somewhere between 245,000 and 295,000 students (Shury et al. 2016). The figures include student numbers where some of these providers had courses with 'designated status' that allowed students with private HE providers to access public-backed tuition fee support. Accordingly, student numbers in private HE (both with public-backed tuition fee support and other) shows significant growth, and the data released by the Student Finance England appear to support this trend (see above SLC, 2018 and HESA, 2018).

However, the growth of private providers in the UK has been continuous since the 1980s. Some studies found around 3,000 colleges of various kinds operating in the UK during 1990s (BAC, 2010). Many small private providers were initially established to accommodate international demand for UK HE - 1980s marked the beginning of higher tuition fees for non-European Union (EU) international students and private providers found a niche market opportunity. Not only did private providers prepare international students for professional and/or preuniversity courses but also prepared students for degree courses, mostly in collaboration with UK universities, for a lower fee (Mariampillai, 2014). In this context, collaborative HE involving private providers mutually benefited both publicly funded universities (i.e. with recurrent funding from the Funding Councils or other public bodies) and private providers. The term collaborative HE provision is used here to identify arrangements for delivering learning and teaching opportunities with organisations other than the degree-awarding body (QAA: Chapter B10, 2012). Collaborative HE provision with private providers offered an additional source of income for universities and by recruiting international students private providers were able to benefit financially and were able to contribute to the overall export earnings for the economy. In this context, private providers began to play a significant role in mainstream HE provision in the UK with little or no regulation and/or scrutiny.

In terms of global outlook, student numbers in private provision has seen a significant increase. For example, the scale of private provision is highest in South Asia and Latin America (54.7\% and 48.8\% respectively in 2010) (PROPHE, 2010). In Asia, many governments are under pressure to expand $\mathrm{HE}$ enrolments to improve global competitiveness of their respective HE systems (Mok, 2009). To achieve this, states are turning to the market and to the private sector (Mok, 2009, p.36). But in most of Latin America, on the other hand, traditionally private HE has grown out of the efforts of the Catholic Church, a significant force in society (Bernasconi, 2010; Neave, 2007). For example, the Catholic University in Chile emerged in 1888 as a response to the state's overall control in education (Bernasconi, 2010). In countries like Chile, the rapid expansion of private HE was made possible by the high demand and a favourable regulatory environment (Bernasconi, 2006). For example, in the early 1980s, the military government (1973-1990) turned its attention to $\mathrm{HE}$ and created new private 
universities; the University of Chile and the State Technical University were also transformed into fourteen small, independent public institutes and universities (Bernasconi, 2010).

In western Europe publicly funded HE institutions have had the dominant role (Levy, 2012). According to Levy the 'statist tradition' (p.183) - a tradition that expects 'welfare goods would be publicly funded and provided' is limiting the prospects of private HE in Europe. But, in contrast, eastern and central Europe have seen an exponential growth of private HE providers (Giesecke, 2006). This prompts Neave (2007) to offer an interesting perspective which finds dissimilarities in the trends of privatisation in western and eastern Europe. Neave (2007, p.37) identifies a paradox in the process of privatisation in eastern and central Europe as compared to western Europe - in eastern and central Europe the collapse of moral, political and financial aspects of the state administration (moral - refers, in particular, to the fall of Soviet Union and the changing values and assumptions about a particular structure) encouraged privatisation of HE. In western Europe according to Neave, privatisation required the intervention of the state. The intervention of the state in the process of privatisation is apparent in the UK and has its own implications. The following section will examine the latter, using a component of a larger study (Mariampillai, 2014), with the data collected from a sample of 19 participants representing the public-private HE provision in the UK. In total 19 interviews were conducted using a semi-structured interview schedule and the participants were chosen purposively, broadly based on their HE experience, seniority and the nature of organisation they represent (i.e. university and/or private college and HE policy institution). Interviews were audiorecorded and transcribed verbatim in preparation for the thematic analysis of the content. Identified themes were reviewed, defined and appropriate titles were allocated.

\section{PRIVATE HE: UNCONTROLLED GROWTH TO STEERED EXPANSION}

This section now turns to the findings in respect of study participants' perceptions on the growth of private HE in the UK. The findings showed that the growth of private HE providers in the UK has come as a surprise to many HE stakeholders and only since 2010 the governments have begun to catch up with their policy making related to private providers.

Two key themes have emerged from the in-depth interviews. Firstly, the absence of robust regulatory environment around private HE provision enabled private HE providers to operate and grow in an unsystematic way with less and/or no public interest up until 2010, when immigration and student visa system abuses in general started to generate serious public discussion (please note the introduction of Tier 4 in 2009 and the government consultations on student immigration in 2010).

Private providers have sprung up and expanded in an unsystematic way because by definition they are outside of the public policy on education (HE Consultant, UK (R3))

Yes if new set-ups focus on UK market there would be no regulatory need for them to approach particular body to gain accreditation or to gain recognition. We did find when the tier- 4 was set up we saw the number of applicants come to us grow quite considerably, naturally, and it was very interesting to see the number of very well established organisations that have been existing for years, normally in a partnership with UK university who haven't approached any organisations for accreditation, they haven't needed it (Senior Executive, Quality and Accreditation (R4)).

The above two comments capture the pre-2010 uncontrolled growth and existence of private HE providers in the UK. Secondly, the post-2010 approach to private HE providers in the UK came with the new regulatory prerequisites that were aimed to steer private provision towards governments' policy aspirations. At the risk of oversimplifying, the then Coalition 
Government's drive to support private providers focused on widening access to education and creating competition and innovation within the sector (Department for Business, Innovation and Skills, 2011; Middlehurst and Fielden, 2011). The following excerpt from the announcement made in 2010 by the then Minister of State for the Universities and Sciences, David Willetts, captured the Coalition Government's thinking on private HE at the policy level:

It is healthy to have a vibrant private sector working alongside our more traditional universities. International experience shows a diverse range of higher education providers helps widen access, focuses attention on teaching quality and promotes innovative learning methods, such as web-based distance learning. We want to see a higher education sector that is dynamic and flexible and focussed on the needs of students and employers (Department for Business, Innovation and Skills, 2010)

The above contention depicts UK governments' (post-2010) aspiration pertaining to the future trajectory of $\mathrm{HE}$ in the UK. The successive governments' policy aspirations focus on competition and innovation in the HE sector - they hoped to achieve these means through the market-centric reforms that transfers power in the hands of students. In the UK, the state's intervention in the privatisation process is evident from its declared intention to open the HE market to various alternative providers (private for-profit and/or not-for-profit). By doing so, the government aimed to intensify the current levels of competition in the HE sector with the view to enhancing students' choices (Department for Business, Innovation and Skills, 2011).

The successive Governments' steering concerning private provision is twofold. On the one hand they want the private providers to play a major role in UK HE (see R6 and R4 below), but on the other hand they realise that the private sector needs to be regulated and brought on par with other HEIs (the state as a regulator - Agasisti and Catalano, 2006).

Over the past few years, I would say the private sector in education have grown enormously. But recently because of certain concerns and funding issues I think the government is trying to squeeze most private institutions [....] (Senior Manager, Private College (R6)).

[......] eventually leads through to private institutions' receiving students with student loans, so which does possibly mean that the private education in HE will open up much more for the UK student market than it has previously. So that's very much a positive from a private HE perspective (Senior Executive, Quality and Accreditation (R4)).

Firstly, the governments' policies were aimed to enhance student choice thus policies were designed to ease the barriers for various HE providers to enter the HE market (Department for Business, Innovation and Skills, 2011). Secondly, the government intends to speed-up the system for new providers to achieve taught degree awarding powers (TDAP). The White Paper, Success as a Knowledge Economy: Teaching Excellence, Social Mobility and Student Choice, which sets out the rationale for the Higher Education and Research Bill, builds on the changes created by the then Coalition Government to enable greater competition within HE by reducing barriers to entry (Department for Business, Innovation and Skills, 2016).

In the meantime, the governments continue to regulate and control the private sector which, in the past stood outside the public policy framework and has mainly focused on different target audience i.e. international students. As respondents suggest below, the successive UK governments have begun to exert their control over the private sector and it is re-shaping the nature and composition of these providers.

The number of private education institutions [........] has been radically reduced by the combined effects of moving towards tighter student visa controls; there are 
discriminatory decisions such as the lack of work study arrangements for private sector students compared to public sector students (HE Consultant, UK and US (R11)).

Over the past few years, I would say the private sector in education have grown enormously. But recently because of certain concerns and funding issues I think the government is trying to squeeze most private institutions [....] (Senior Manager, Private College (R6)).

Therefore, since 2010 the relationship between the state and private HE providers in the UK has begun to take a new outlook. The autonomy enjoyed by the private HE sector and providers in the UK has been compromised and the state has begun to impose its boundaries within the private sector as it did with public universities (Tapper and Salter, 1995). By doing so, the government has deliberately transformed the private sector and providers to resemble universities. Thus, the governments' policy strands represent a dual trajectory in the context of private HE providers. In this context, the government is seen as a regulator (Agasisti and Catalano, 2006) and a deregulator. Thus, these policy developments have managed to inflict a change in the shape of the post-2010 private HE provision in the UK.

Consequently, following a period of uncertainty and regulatory turmoil a new market opportunity has been presented to private HE providers in the UK. Private providers have been deliberately pushed to focus on national students (home and EU) with access to public-backed funding. As respondent R3 remarked, the changes in UK tuition fees have prompted private HE providers, with the new status quo, to play a significant role within the UK HE provision.

It may well be the case with the changes in university finances and tuition fees [publicbacked funding] that they will be targeting more markets to a greater extent possibly undercutting university fees (HE Consultant, UK (R3)).

In April 2011, the then Coalition Government announced that private providers teaching on courses in 2012-13 would be able to access $£ 6,000$ in public-backed loans. Private providers responded to this opportunity, and they did so through Higher National Certificate/Diploma (HNC/HND), a qualification awarded by Pearson's Edexcel. Private providers who previously had no access to public-backed funding have been given millions of pounds of public funding. For example, in the 2015-16 academic year, the government paid out $£ 417$ million in tuition fee loans, maintenance loans and grants to private HE providers and their students (House of Commons Committee of Public Accounts, 2018). This has generated much public discussion and scrutiny - ironically concerns on quality and students' experience within private HE provision generated less interest during times when private providers heavily relied on nonEU international students.

If liberalising the HE market is seen as a move towards widening access to education and enhancing student choice, then the Governments' initiatives are heading in that direction, but with limited success. It appears that the successive Governments' supply-side reforms since 2010 have opened a new space for the second wave of uncontrolled expansion of private HE providers in the UK. But, this time around the expansion has generated a significant public interest, debate and scrutiny. The reports published by the House of Commons Committee of Public Accounts (2015 and 2018) identified clear failings in measuring the success (or risks) of widening access to education provision. For example, around $£ 4 \mathrm{~m}$ of public-backed funds were paid to ineligible EU students. It appears that there is a strong case for further and continuous Government intervention and control (for example, see Clark, 2015), at least in the case of the private HE sector and its expansion. The Office for Students (OFS) has taken the responsibility for regulating all English HE institutions, including all private HE providers, since April 2018. 
Given the pressing issues such as high numbers of students dropping out of their courses (noncontinuation rate $38 \%$ in 2012/13 and 25\% in 2014/15,) in private HE provision (House of Commons Committee of Public Accounts, 2018), the sector will see different faces of the regulator's steering approaches.

\section{CONCLUSION}

Evidence suggest that there has been a significant presence of private HE provision in the UK before 2010, but it failed to attract attention at the academic and policy levels due to two main reasons: (a) a significant number of private HE provider students were non-EU international students and the immigration system then favoured more international students; and (b) not many private HE providers were approved to access public-backed funding. In contrast, the growth in private provision that has occurred since 2010, attracted enormous public interest as it involved millions of pounds of public money in private organisations. According to the analysis of data released by the Student Finance England, around $80 \%$ of the student numbers are linked to 25 private providers and the rest of the $20 \%$ are linked to 58 small private providers (SLC, 2015). In this context, one can conclude that there has been a significant expansion of a small number of large private providers since 2010. It presented a challenge for policy-makers to establish whether such concentration of students and public money within a small number of private providers offer any benefits.

It seems like the Coalition Government's commitment to open-up (deregulate) the HE markets has re-defined the relationship between the government and private HE providers. Private providers who managed to function partly outside the public policy have lost their autonomy and are made to operate within an externally set boundary, which offers an opportunity for close scrutiny.

There is no doubt, at the very least in my mind, that any legitimate HE system that meets the aspirations of students who have been previously excluded from the traditional HE system should be publicly-funded and supported. In this context, the Government's idea of widening access to education has significant currency. One of the criticisms made of the then Coalition Government and its use of public funding for private providers is that the Government failed to learn from the American experience (University and College Union, 2014). That is, in the US private for-profit HE saw a rapid growth of companies making excessive profits out of HE with high level of drop-outs (Middlehurst and Fielden, 2011). To a certain extent, similar concerns are currently recognisable within the UK private HE sector. For example, one of the UK's biggest private HE providers, GSM London, has recently gone into administration, closing doors to around 3500 enrolled students.

It is easy to conclude that the successive Governments' choice of instruments and approaches to manage and organise private provision lacked clear understanding of the private sector and experience. The experiences gained from pre-2010 expansion and behaviours of private providers should have been consulted prior to opening up the UK HE market to private providers. Unfortunately, there appears to be a continuing conviction at the policy-making levels to manage private providers like other publicly-funded universities. I agree with Morris (2014) who calls for robust and transparent public and corporate governance structures to facilitate stakeholders' confidence in a HE system regardless of its ownership. How could this be achieved? As a newly designated regulator OFS has a significant role to play in the sector. 


\section{References}

Agasisti, T., and Catalano, G. (2006) Governance models of university systems: Towards quasi-markets? Tendencies and perspectives: A European comparison. Journal of Higher Education Policy and Management, 28(3), p. 245 - 262.

Ball, S. J. (2007) Education PLC: understanding private sector participation in public sector education, London and New York: Routledge.

Ball, S. J. (2013) The Education Debate, $2^{\text {nd }}$ ed. Bristol: Policy Press.

Bernasconi, A. (2006) Does the affiliation of universities to external organizations foster diversity in private higher education? Chile in comparative perspective. Higher Education, 52(2), p.303-342.

Bernasconi, A. (2010) Chile's Dominant Private Higher Education. ASHE Higher Education Report Special Issue, 36(3), p. 23-35.

British Accreditation Council (2010) A History [Online] Available at: http://www.thebac.org/sites/default/files/documents/BAC\%20History.pdf (Accessed on 20/02/15).

Clark, G (2015) House of Commons: Written Statement (HCWS239), 29 January 2015 [Online] Available at: http://www.parliament.uk/documents/commons-vote-office/January\%202015/29\%20January/1.BIS-HigherEd.pdf (Accessed on 02/02/2018).

Department for Business, Innovation and Skills (2010) Willetts supports BPP in becoming a university college [Online] Available at: https://www.gov.uk/government/news/willetts-supports-bpp-in-becoming-a-universitycollege (Accessed 03/04/2019).

Department for Business, Innovation and Skills (2011) Higher education: students at the heart of the system. London: Department for Business, Innovation and Skills.

Department for Business, Innovation and Skills (2013) Privately funded providers of higher education in the UK. London: Department for Business, Innovation and Skills.

Department for Business, Innovation and Skills (2016) Success as a Knowledge Economy: Teaching Excellence, Social Mobility and Student Choice. London: Department for Business, Innovation and Skills.

Giesecke, H. (2006) Legitimacy Seeking among New Private Institutions of Higher Education in Central and Eastern Europe. Higher Education in Europe, 31(1), p. 11-23.

Higher Education Statistics Agency (2018) Higher Education Student Statistics: Alternative Providers, 2016/17 Summary [Online]. Available at: https://www.hesa.ac.uk/news/15-02-2018/sfr249-higher-education-studentstatistics-APs (Accessed on 12/07/19).

House of Commons Committee of Public Accounts (2015) Financial support for students at alternative higher education providers (HC811), London: The Stationery Office Limited.

House of Commons Committee of Public Accounts (2018) Alternative Higher Education Providers: Twenty-Third Report of Session 2017-19 (HC736), London: The House of Commons.

Jongbloed, B. (2003) Marketisation in Higher Education, Clark's Triangle and the Essential Ingredients of Markets. Higher Education Quarterly, 57(2), p. 110-135.

Levy, D. (2012) How Important Is Private Higher Education in Europe? A Regional Analysis in Global Context. European Journal of Education, 47(2), p.178-197.

Mariampillai, J. (2014) Collaborative provision within UK higher education: perceptions of stakeholders of UK and Sri Lankan private colleges offering university degrees in business and management. Unpublished doctoral thesis, University of West London, London.

Middlehurst, R. and Fielden (2011) Private Providers in UK Higher Education: Some Policy Options. Higher Education Policy Institute: UK.

Mok, H. K. (2009) The growing importance of the privateness in education: challenges for higher education governance in China, Compare, 39(1), p.35-49.

Morris A. (2014) Maligned and misunderstood: the PAC should rethink stance on private providers, 12 December 2014 [Online] Available at: http://www.timeshighereducation.co.uk/comment/opinion/private-providersmaligned-and-misunderstood/2017473.article (Accessed on 10/03/2018).

Neave, G. (2007) The long quest for legitimacy: an extended gaze from Europe's Western parts, In: S. Slantcheva and D.C. Levy (Eds.) Private Higher Education in post-Communist Europe: in search of legitimacy, New York: Palgrave Macmillan, p. 27-53. 
Program for Research on Private Higher Education (2010) Country data summary, [Online] Available at: http://www.albany.edu/dept/eaps/prophe/international databases.html (accessed on 18/07/2019).

Quality Assurance Agency (2012) Assuring and enhancing academic quality: chapter B10managing higher education provision with others. Gloucester: Quality Assurance Agency.

Shury, J., Adams, L., Barnes, M., Huntley, Hewitt, J., and Oozeerally, T. (2016) Understanding the market of alternative higher education providers and their students in 2014. London: IFF Research.

Students Loan Company (2015) Higher Educations Statistics for England [Online] Available at: http://www.slc.co.uk/official-statistics/financial-support-awarded/england-higher-education.aspx (Accessed on 20/02/18).

Students Loan Company (2018) Student Support for Higher Education in England 2018 [Online] Available at: https://webarchive.nationalarchives.gov.uk/20190510151948/https://www.slc.co.uk/media/10180/slcsfr0520 18.pdf (Accessed on 10/08/19).

Tapper, T. and Salter, B. (1995) The changing idea of university autonomy. Studies in Higher Education, 20 (1), p. 59-71.

University and College Union (2014) The private providers' 'designation' bonanza (UCU briefing), London: University and College Union. 